\title{
TAKAFUL AGENT MUST FOSTER PUBLIC UNDERSTANDING OF TAKAFUL
}

\author{
Muhammad Adi Zhafri Ahmad Samsuri \& Jasri Jamal \\ Faculty of Law, Universiti Kebangsaan Malaysia \\ jasri@ukm.my
}

\begin{abstract}
The Takaful industries need agents to market the Takaful products to the public. Takaful agents play a great role in current marketing practice for Takaful distribution. Besides representing their operators and products, the agents would present this Takaful as an Islamic Insurance. The agents need to foster public understanding of Takaful instead of Conventional Insurance. To achieve this, all of the values as stated in the Al-Quran and practice through the Sunnah will be implemented by the Takaful agents to realize the objective of Takaful as an Islamic alternative for conventional Insurance. Of course this can be an option for the public to choose either one, but still, as Muslim people, we should support Takaful for Muslim sake.
\end{abstract}

Keywords: Takaful, Takaful agent, Takaful Marketing, Islamic Insurance

\section{Introduction}

The Takaful industry comes to new developments, challenges, and opportunities. The challenge ahead will be to anticipate and make the most of the changes and opportunities. The Takaful industry has remained remarkably resilient and continued to grow from strength to strength. With increasing liberalization and globalization of world trade, there is a new horizon of opportunity for Takaful operators. In what some have dubbed the "new age" of competition, creativity and innovation will become critical ingredients for success. Those who rise to this challenge will reap the rewards. Those who do not will fall and be forgotten.

Nowadays, we can see so many Takaful operators in Malaysia. There are lots of Takaful products being offered in Malaysian financial industry. But still, many Malaysian people choose Conventional Insurance instead of Takaful Insurance for Muslims themselves. This phenomenon is not good for Muslim people as they should support Muslim product. The Takaful agents need to strengthen their efficiency and effectiveness in marketing channels. This is because Takaful 
industries rely on their agencies system as it is the main medium for marketing the Takaful products recently.

The responsibility to sell the Takaful products is on the Takaful agents' hand. The agents must have excellent knowledge of their products together with good skills to market them. It is important also for the agents to practice the Islamic marketing to approach the public. However, the majority of them tend to stress only on profit or commission in the marketing activities like the agents employed by the conventional insurance industry.

The studies on Takaful have started since the 1990s and initially but the focus is only on its conceptual and operational basis. In the 2000s, researchers start to gauge the public perception towards Takaful products. Some researchers have been interested in looking at the understanding and knowledge of Malaysian particularly the Muslims regarding the Takaful products. Among them are, Syukriyah (2004), Mohamad and Mohd Sukki (2009), and Noor Hashim (2009). Some researchers are interested in looking at the level of awareness ${ }^{1}$. They found that the Muslims are aware of Takaful. However, their level of confidence towards the products concerning the preparation for the future financial protection is still low.

Therefore, this paper tends to fill the knowledge gap and contributes to strengthening the marketing practice of the Takaful agents. This paper thus aims to discuss the Takaful Agent Needs to Foster Public Understanding of Takaful. The aspects of Islamic marketing are also highlighted in this paper. It is structured as follows: first, some literature review about the Takaful industry and the roles of Takaful agents. It is followed by a discussion on the role of agents from the Islamic perspective together with Islamic aspects of marketing. Finally, there is a conclusion and suggestion for future research.

\footnotetext{
${ }^{1}$ Yon Bahiah, W.A., Siti Zaleha, S., \& Norshahida, S. A Relook into Awareness, Perceptions, Barriers, and Future Insurance Needs: A Case Study of Takaful and the Malays. CD-ROM Conference of the International Journal of Arts and Sciences, 2009. 1(19): 10-21.
} 


\section{The Common Views}

For Takaful to stay relevant, the Takaful industry must position itself within the hub of the mainstream financial system. It must be able to compete and offer products and services that are on par, if not better than conventional insurance products. To achieve this, several conditions must be in place. Among them is a higher degree of consensus on the interpretation of Syariah principles in the context of Takaful operations, a cohesive regulatory and legal framework which emphasizes transparency, consumer protection, and corporate governance, as well as uniform accounting standards to lay the foundation for further growth and expansion.

As the industry progresses, the capacity of Islamic reinsurance or retakaful and a pool of expertise within the Islamic business circle will also be needed to support its ongoing development. The Takaful industry needs to develop new strategies to achieve these requirements and take full advantage of the opportunities. So the continuity of Takaful can be assured and prolong its lifespan.

The agents are responsible for assisting their customers in all circumstances related to their financial well-being and to spread knowledge of Takaful to Muslims and non-Muslims ${ }^{2}$. All of the agent must undergo thorough preparation and be properly informed of the necessary information, skills, and strategies in order to properly execute their responsibilities. Takaful agents are required to be vigilant and are responsible for losses arising from carelessness ${ }^{3}$.

As Takaful stride forward, it is often useful to take a moment to ponder on past achievements and failures, and lessons learned along the way. As one of the pioneers in the development of the Takaful market in this region, Malaysia's experiences may prove useful in providing some direction and focus on future endeavors.

\footnotetext{
${ }^{2}$ IBFIM (Islamic Banking and Finance Institute Malaysia). Buku Panduan Asas Takaful. Kuala Lumpur: Islamic Banking and Finance Institute Malaysia Sdn. Bhd, Kuala Lumpur, Malaysia. 2011.

${ }^{3}$ Frenz, T., \& Soulhi, Y. Takaful and Retakaful: Advanced Principles and Practices. IBFIM and Munich Re, Kuala Lumpur, Malaysia. 2010.
} 


\section{Result and Discussion}

\subsection{The Takaful Brief History}

The wish of Muslims to enjoy the benefits of a modern banking and insurance system but on a basis which is not forbidden by Islam was the impetus to the development of Islamic banking and insurance in Malaysia. The Malaysian Government established a special task force back in 1982 to study the possibility of introducing Islamic insurance to complement the services of Islamic banking. Following the recommendations of the task force, the Malaysian Parliament passed the Takaful Act in 1984, making Malaysia probably the only country in the world to have a specific legislation governing Takaful business. The first Takaful operator was hatched in 1984 and another, about a decade later.

Over the past three years, with the admission of the second Takaful operator, the Malaysian Takaful industry proceeded to record commendable growth, with assets and contribution income expanding at average rates of $45 \%$ and $49 \%$ respectively. The onset of the unprecedented regional financial crisis in mid-1997 has not stifled the growth momentum of the Malaysian Takaful industry. While the conventional insurance sector wrestled to regain eroded market positions, the Takaful sub-sector in Malaysia continued to maintain strong double-digit growth. The total assets of the Takaful funds continued to expand at $26 \%$ in 1998. The combined contribution income of both family and general Takaful business also increased by $40 \%$, higher than the growth rate of $34.9 \%$ recorded in 1997.

Efforts to promote Takaful business saw Takaful operators embarking on measures to diversify their distribution channels, launch new products and organize customized training programmes for their staff and agents. In addition to the normal lines of Takaful products, new products recently introduced in Malaysia include a special product for women and health Takaful. The wider range of products and distribution channels available helped to spur the growth of Takaful in Malaysia. Interestingly, as the insuring public in Malaysia became more discerning, efforts made by the Takaful operators to increase public awareness of Takaful products have also attracted the non-Muslim community. The Al-Mudharabah or profit sharing principle, one of the unique features inherent in Takaful products, makes Takaful an attractive alternative to conventional

Diponegoro Law Review, October 2017, Volume 02, Number 02 
insurance. This is attributed in no small measure to the high level of religious tolerance among Malaysians which enabled Takaful to gain acceptance among the non-Muslim population.

Throughout the development of the Takaful industry in Malaysia, the Government and regulatory authorities have been careful to preserve the fundamental Islamic principles on which Takaful business is founded. The availability of expertise in both Islamic insurance and Syariah matters has and will continue, to remain a priority in order to safeguard the integrity of Takaful practices. With the commitment of regulators and support of practitioners, Malaysia is progressively building up a pool of technical knowledge and expertise to support the development of Takaful both domestically as well as abroad. In 1997, Malaysia established a Syariah Advisory Council at the Central Bank to act as an authoritative reference point on issues relating to Islamic banking and Takaful. The Takaful industry has also recently taken steps to draw up a code of conduct for Takaful operators, which will promote good market conduct and practices, and instill professionalism among practitioners. The code will promote healthy competition by creating a more level-playing field for both conventional insurers and Takaful operators through common market practices.

Although the Takaful industry has made its mark and the growth has been significant so far, the industry remains small relative to conventional insurance. At the end of 1998, Takaful contribution in Malaysia represented only $2 \%$ of conventional insurance premium, while Takaful assets stood at only $1.6 \%$ of conventional insurance assets. The potential for the Malaysian Takaful industry to grow is tremendous. This two major factors namely, the low level of life insurance penetration among the majority Muslim population and the overall low penetration rate of $27 \%$ in Malaysia. Outside Malaysia, there is also an enormous growth potential for the Takaful industry given that there are nearly 1.7 billion Muslims worldwide, more than a quarter of the world's population. With Islam being the second largest religion in the world, this number is expected to grow, and at a rapid pace. These factors, coupled with an increasing Islamic consciousness among Muslims, will not only sustain the present momentum but has the capacity to propel the Takaful industry to a new phase of development and achievement. Our home-grown Takaful operator had taken cognizance of this opportunity and has already ventured abroad by participating in equity interests in a Takaful company outside Malaysia. Through its presence abroad, the operator is also 
able to provide technical assistance and at the same time propagate the development of Takaful outside the country.

Now, the regulatory and supervisory framework of Malaysia enters a new stage of its development as the Financial Services Act 2013 (FSA) and Islamic Financial Services Act 2013 (IFSA) come into force on 30 June 2013.

The introduced FSA and IFSA is the culmination of efforts to modernise the laws that govern the conduct and supervision of financial institutions in Malaysia to ensure that these laws continue to be relevant and effective to maintain financial stability, support inclusive growth in the financial system and the economy, as well as to provide adequate protection for consumers. The laws also provide the Central Bank with the necessary regulatory and supervisory oversight powers to fulfill its broad mandate within a more complex and interconnected environment, given the regional and international nature of financial developments. This includes an increased focus on preemptive measures to address issues of concern within financial institutions that may affect the interests of depositors and policyholders, and the effective and efficient functioning of financial intermediation.

It is very important that Malaysia's regulatory and supervisory system is adequately equipped to respond effectively to new and emerging risks so that confidence in the financial system is preserved and that the critical financial intermediation activities which are vital to the economy are not disrupted. The FSA and IFSA amalgamate several separate laws to govern the financial sector under a single legislative framework for the conventional and Islamic financial sectors respectively, namely, the Banking and Financial Institutions Act 1989 (BAFIA), Islamic Banking Act 1983, Insurance Act 1996 (IA), Takaful Act 1984, Payment Systems Act 2003 and Exchange Control Act 1953 which are repealed on the same date.

The key features of this new legislation include greater clarity and transparency in the implementation and administration of the law. This includes clearly defined regulatory objectives and accountability of Central Bank in pursuing its principal object to safeguard financial stability, transparent triggers for the exercise of Central Bank's powers and functions under the law, and transparent assessment criteria for authorizing institutions to carry on regulated financial business, 
and for shareholder suitability; a clear focus on Shariah compliance and governance in the Islamic financial sector. In particular, the IFSA provides a comprehensive legal framework that is fully consistent with Shariah in all aspects of regulation and supervision, from licensing to the winding-up of an institution; provisions for differentiated regulatory requirements that reflect the nature of financial intermediation activities and their risks to the overall financial system; provisions to regulate financial holding companies and non-regulated entities to take account of systemic risks that can emerge from the interaction between regulated and unregulated institutions, activities and markets. The Minister of Finance may subject an institution that engages in financial intermediation activities to ongoing regulation and supervision by Central Bank if it poses or is likely to pose a risk to overall financial stability; strengthened business conduct and consumer protection requirements to promote consumer confidence in the use of financial services and products; strengthened provisions for effective and early enforcement and supervisory intervention.

The new laws will place Malaysia's financial sector, encompassing the banking system, the insurance or takaful sector, the financial markets and payment systems and other financial intermediaries, on a platform for advancing as a sound, responsible and progressive financial system. This is especially important to enable the financial system to meet the new demands for financing associated with Malaysia's economic transformation programme both during and beyond the next decade, the changing demographics of the Malaysian population, and the increasing integration of the Malaysian economy with the region and the world.

\subsection{The Market Opportunity of Takaful}

There is a ready market for Takaful. The secret in tapping that market lies in creating value. This value can be realized if the right combination of success factors can be created. For Takaful to be successful, Government support, cooperation at the international level and the development of human capital are essential. The foresight shown by Islamic countries under the Developing Eight to take the lead in fostering closer cooperation and coordination, promoting greater exchange of business and developing technical know-how to develop the Takaful industry is very impressive.

Active Government support within the domestic market is equally important. Recognising the potential of Takaful business to grow into one of the key components of the Malaysian financial 
system, the Malaysian Government has given its unwavering commitment and support to the development of a viable and resilient Takaful sector. The result has been the development of a dynamic and competitive Takaful industry in Malaysia.

As the regulator of both the conventional insurance and Takaful industries, the Central Bank of Malaysia plays an active role in spearheading Takaful development in Malaysia. To tap the tremendous potential in the Takaful industry, the Central Bank has drawn up a five-year strategic plan in consultation with the statutory associations, conventional insurers, and Takaful operators. The strategic plan focuses on some areas of development, each with defined objectives and strategic action plans.

\subsection{The Five Year's Plan}

Central to the plan are specific targets set for the Takaful industry to achieve over the next five years. The targets include market penetration of family business of $7 \%$ of the Malaysian population and total contribution income of both the general and family Takaful business to reach $7 \%$ of the total premium income of the conventional insurance sector.

These targets are supported by strategies to enhance the market penetration of Takaful business by allowing more players into the market, promoting the diversification of marketing channels, encouraging product innovation and instilling a greater public awareness of the benefits of Takaful. The plan also sets out strategies to strengthen the financial soundness of Takaful operators and the regulatory framework governing the Takaful industry. These strategies are rooted in specific action plans to achieve the ultimate objectives under the strategic five-year plan. They include; a comprehensive review of the Takaful Act by the Central Bank to replace the existing regulatory framework with a more comprehensive legislation that incorporates the experience thus far gained from administering both the existing Takaful and conventional insurance legislation; the introduction of model accounts and new statistical statements to ensure minimum reporting standards, greater disclosure of financial information and transparency of operations; measures to promote regional expansion and international cooperation in Takaful; and measures to develop Malaysia into a centre for Takaful training and education.

\section{2}

Diponegoro Law Review, October 2017, Volume 02, Number 02 
The progressive implementation of the strategies outlined in the five-year plan should see the Takaful sector evolve into a significant sub-sector of the Malaysian insurance industry in the coming years.

Over the next five years, a few additional Takaful licenses will be issued to eligible parties. Preference will be given to strong financial institutions with a well-established Islamic banking or conventional insurance set-up. Strong non-financial institutions with a good financial track-record will also be considered. Foreign investors with expertise in Takaful are welcome to establish jointventures with Malaysian partners. Eligible foreign investors a stake of up to $49 \%$ in a joint-venture also will be considered. Takaful licenses will be issued as an incentive to encourage mergers and acquisitions among conventional insurers.

Human capital represents the third and possibly most important dimension to the successful development of a Takaful industry. Without a doubt, the most valuable assets for any business in the $21^{\text {st }}$ century will be knowledge and information-based. A knowledgeable and skilled workforce is the key to sustaining a competitive advantage. As a strategy, Takaful operators should be capable of developing a motivated, innovative and adaptive workforce that is capable of creating and adding value for its customer. It is imperative that they are also well-versed in Syariah matters. Only then, can the Islamic principles be integrated with the dynamics of the business world? Syariah scholars play a fundamental role in guiding Takaful operations. For them to effectively fulfill this role, they have to be conversant with the practical aspects of Takaful business. Through appropriate rulings and recommendations on specific matters, Syariah scholars can expand the breadth and depth of Takaful business, but within the bounds of Syariah.

Training institutes have an important role to play in enhancing and developing world-class training programmes suited to the needs of the Takaful industry. In this respect, the Malaysian Insurance Institute, the leading insurance training institute in Malaysia, has already developed several programs to increase the level of expertise in the Takaful industry. The Certificate in Takaful Practice, conducted by the Institute, has been well received by both the insurance and Takaful industries. 
The Takaful industry is set to change insurance markets in a significant way. As with any change, new frontiers can be both exciting and daunting. Takaful operators, Syariah scholars, and regulators have not only an interest but also a joint responsibility, to ensure the orderly and progressive development of the Takaful industry.

\subsection{The Factors That Influences People to Buy Takaful Product}

From research conducted by Kamil and Mat Nor (2014), there is a consensus in the views of the respondents regarding the factors that influence the choice of Malaysian people buying Takaful products. Respondents are of the views that change from conventional insurance to Takaful is an obligation to avoid gharar, maysir, and riba which are prohibited in Islam.

From the research stated above we can simply conclude that the factors can be divided into three main factors; firstly, the reliability of agents. The trusted agent is the best. The top agent or the famous agent can attract more people than the newbie agent. So the agents need to score according to this factor. They need to improve their public relations to easily encourage people ${ }^{4}$.

Second, people awareness is also the important thing here. The agents must implement in the people mind that Takaful is the Islamic Insurance and they must choose it instead of Conventional Insurance because Conventional Insurance contain gharar, maysir, and riba which are prohibited in Islam but Takaful is free from those three. So, by choosing Takaful, Muslim people also do ibadah.

Lastly, the power of choose. Before Takaful enter the financial industry, there is only Conventional Insurance in the market. But now there is no excuse more for Muslim people because recently there is huge number of Takaful operators and Takaful agencies in Malaysia. So the Muslim and Non-Muslim People can choose these Takaful products for their sake.

These factors of gharar, maysir, and riba which are embedded in the conventional insurance are among the factors that influence respondents to migrate from conventional insurance to Takaful products. Respondents seem to unanimously agree that as Muslims they must not choose

\footnotetext{
${ }^{4}$ Aziz et al., Issues and Problems in Ethical Practises amongst Takaful Agents. International Review of
} Management and Marketing. Vol. 6 Special Issue (S4). 2016. P 23.

\section{4}

Diponegoro Law Review, October 2017, Volume 02, Number 02 
conventional insurance scheme and they also must support Takaful ${ }^{5}$. They must make attempts to protect their religious duties, thus, safeguard their akhirah as well as their worldly living. This seems to suggest that, taking the obligation to find avenues to protect one's religious duties and life can be considered as acts of worship (Ibadah).

\subsection{The Takaful Agents Roles According to The Qur'an and Sunnah}

The word 'agent' or 'wakeel' in Arabic term has appeared in the Qur'an repeatedly. It signifies the act of a person to represent another person in certain dispositions. As in Surah al-Kahfi (verse 19), Allah (s.w.t) has mentioned about the role of a wakeel or agent as follows:

"When we resurrected them, they asked each other, "How long have you been here?" "We have been here one day or part of the day," they answered. "Your Lord knows best how long we stayed here, so let us send one of us with this money to the city. Let him fetch the cleanest food, and buy some for us. Let him keep a low profile, and attract no attention." (Al-Quran 15:19).

Meanwhile, the word 'wakeel' could mean to preserve or defend (hifz) and was stated in the Qur'anic verses (for example, 3:173 and 4:132). It also means to entrust (tafwid) as in Qur'anic verses (for example, 3:160 and 12:67) and also to be responsible for arranging one's affair (stated in Qur'an verse 6:66 and 6:107) (Hairul Azlan, 2004). Among the Hadith of Prophet Muhammad (pbuh) that has mentioned about the role of wakeel or agent is: The Prophet (pbuh) asked Jabir ibn Abdullah, who was about to go to Khybar: "If you meet my agent, take or ask from him fifteen wasq." (Abu Dawud, al-Bayhaqi, al Daraqutni, and al-San'ani).

It is clearly mentioned that Prophet Muhammad (pbuh) used the term 'agent' or wakeel on his behalf to settle his duties on above Hadith. These prominent Islamic resources (Al-Qur'an and Hadith) lay claim to the authenticity of the Wakala model to be experienced in the modern environment particularly in the Takaful industry ${ }^{6}$.

\footnotetext{
${ }^{5}$ Kamil and Mat Nor. Factors Influencing the Choice of Takaful Over Conventional Insurance. Journal of Islamic Finance, Vol. 3 No. 2, 2014, p 9.

${ }^{6}$ Marhanum Che Mohd Salleh. Takaful Agent's Roles in Accordance with the Quran and Sunnah. Global Journal Al Thaqafah, Vol. 2 Issue 2. P 43.
} 
In the context of Takaful, the agents firstly should have a clear intention to sincerely help customers. In this context, Takaful agents should not undermine the noble objectives of Takaful by pursuing their personal interests. This can be done through disclosing all the product details to their customers and suggesting the best products, suitable to the customers' needs in future. They must be honest, responsible, deliver on promises, intelligent, wise, patient and dedicated (IBFIM, 2011).

Second, the agents should play a decisive role in acknowledging Takaful as the best Islamic solution for financial management. Agents are not only liable for selling Takaful products, but to also offer Takaful services. To do this, the agents must have a deep understanding about Takaful itself and the Takaful products of course. Any lack of knowledge about both of its will take away public interest in choosing Takaful instead of Conventional Insurance.

Third, the agents should explain the magnificence of the principle of Tabarru' in Takaful which distinguishes itself from its conventional counterpart. In Takaful, the aim of the scheme is for the benefit of human beings including Muslims and non-Muslims. All agent must deliver this message to the public. Parallel to the objective of Takaful, the contract must be applied according to the concept of Tabarru' and shared responsibility which resonates with the concept of Ibadah in Islam. A hadith of Prophet Muhammad (pbuh) regarding this matter is: He said "The one who looks after and works for a widow and for a poor person (dependent), is like a warrior fighting for the Cause of Allah (s.w.t), or like a person who fasts during the day and prays throughout the night".

Forth, the agents should have the intention to get the blessings from Allah (s.w.t), mentions that: 'the ultimate aim of Takaful agency members (from agency manager, unit manager, specialist, and agents) is to seek the pleasure of Allah, submit entirely to His will and strive toward the final abode in the Hereafter ${ }^{17}$. They are responsible for safeguarding the welfare of the society.

And last, the agents are accountable to educate the public about the main purpose of Takaful products and also the importance to prepare for the financial protection upon their heir. In this regards, Islam has emphasized that Muslims should ensure their heirs' welfare once they died. This in line with one of the hadith of the Prophet Muhammad (pbuh), The Prophet said: "it is better for you to leave your off-spring wealthy than to leave them poor, asking others for help."

\footnotetext{
${ }^{7}$ Aiman., F.Y. Takaful: Effective Marketing and Sales Practices. IBFIM, Kuala Lumpur, Malaysia. 2009.
} 


\section{Conclusion and Recommendation}

This paper focuses on the Takaful Agent Needs to Foster Public Understanding of Takaful. The agents need to study the following propositions and make improvements in their strategy to implement people mind about Takaful with its: i) Takaful customers have a clear concept of Takaful and the requirement of Shariah compliance. Takaful product is necessary for Muslims as replacement of conventional insurance. ii) Takaful customers have awareness of the relationship between Takaful and religion, i.e., Islam in contemporary business. iii) The roles of Takaful agents in explaining the concept of Takaful and the benefits can be considered as aspects of worship (Ibadah). The obligation by Takaful agents in promoting the Takaful product to Muslims can be considered as acts of Dak'wah. iv) The growth of Takaful businesses, however, remains slow compared to conventional insurance. People are hopeful of the growth and development of Takaful operations.

Takaful Operators and Takaful agents may use the findings of this paper to justify their efforts in designing, developing and appropriate promotion and awareness interventions so that Takaful products and sales might witness extensive development in Malaysia. This could lead Malaysians in general and Malaysian Muslims in particular, to further appreciate Takaful products, which is Shariah compliant. As well, non-Muslims in Malaysia, as well as the globe, may also have interest in buying Takaful products if a better approach to them is being made.

\section{References}

Aiman., F.Y. Takaful: Effective Marketing and Sales Practices. IBFIM, Kuala Lumpur, Malaysia. 2009.

Aziz et al, Issues and Problems in Ethical Practises amongst Takaful Agents. International Review of Managementand Marketing. Vol. 6 Special Issue (S4). 2016. P 23.

Frenz, T., \& Soulhi, Y. Takaful and Retakaful: Advanced Principles and Practices. IBFIM and Munich Re, Kuala Lumpur, Malaysia. 2010.

IBFIM (Islamic Banking and Finance Institute Malaysia). Buku Panduan Asas Takaful. Kuala Lumpur: Islamic Banking and Finance Institute Malaysia Sdn. Bhd, Kuala Lumpur, Malaysia. 2011. 
Kamil and Mat Nor. Factors Influencing the Choice of Takaful Over Conventional Insurance. Journal of Islamic Finance, Vol. 3 No. 2, 2014, p 9.

Marhanum Che Mohd Salleh. Takaful Agent's Roles in Accordance with the Quran and Sunnah. Global Journal Al Thaqafah, Vol. 2 Issue 2. P 43.

Mohamad, A. H., \& Mohd Sukki, O. A study on the level of knowledge and understanding among Muslims towards the concepts, Arabic and Shariah terms in Islamic insurance (Takaful). European Journal of Social Sciences, 2009. 10(3). p p 468-478.

Yon Bahiah, W.A., Siti Zaleha, S., \& Norshahida, S. A Relook into Awareness, Perceptions, Barriers, and Future Insurance Needs: A Case Study of Takaful and the Malays. CDROM Conference of the International Journal of Arts and Sciences, 2009. 1(19): 10-21.

Press Statements. Financial Services Act 2013 and Islamic Financial Services Act 2013 ComeIntoForce. cessed (30 May 2016).

Speeches \& Interviews. Governor Tan Sri Ali Abul Hassan;s Speech at the International ConferenceonTakafulhttp://www.bnm.gov.my/index.php?ch=en_speech\&pg=en_speech_all\& ac=72\&la ng=en >accessed (30 May 2016).

Life Insurance Sales Tips and Techniques retrieved from http://www.allwebleads.com/agenttips/life-insurance-sales-tips (30 May 2016).

Mark P. Cussen, CFP, CMFC, AFC. 8 Qualities That Make A Good Insurance Agent. Retrieved from http://www.investopedia.com/financial-edge/1212/8-qualities- that-make-a-goodinsurance-agent.aspx (30 May 2016). 